\title{
Siew New Disease Reports \\ First record of Phytophthora nicotianae causing leaf blight on Dracaena sanderiana
}

\author{
M.V.O. Dos Santos ${ }^{1,2}$, E.D.M.N. Luz ${ }^{1,2 *}$ and J.T. de Souza ${ }^{3}$ \\ ${ }^{1}$ Programa de Pós-Graduação em Produção Vegetal, Departamento de Ciências Agrárias e Ambientais, Universidade \\ Estadual de Santa Cruz, 45662-000, Ilhéus, BA, Brazil; ${ }^{2}$ SEFIT, CEPEC, CEPLAC, Caixa Postal 07, 45600-970, Itabuna, BA, \\ Brazil; ${ }^{3}$ Universidade Federal do Recôncavo da Bahia, CCAAB, 44380-000, Cruz das Almas, BA, Brazil
}

*E-mail: ednadora@yahoo.com.br

Received: 26 Mar 2011. Published: 15 Dec 2011. Keywords: nursery, ornamental plants

Dracaena sanderiana is an ornamental plant from tropical West Africa and well known in Brazil as a tropical garden species. According to local producers it is the most frequently sold ornamental plant in Bahia State. During surveys conducted between August and September 2008 in eleven ornamental nurseries of Uruçuca municipality in Bahia State, Brazil, various plants of $D$. sanderiana showing leaf blight were observed in three nurseries. Seven isolates of Phytophthora sp. were obtained from diseased leaf tissues and also from the rhizosphere of diseased plants of $D$. sanderiana through soil dilution plating on selective medium PARPH (Kannwischer \& Mitchell, 1978).

Seven-day old colonies of all isolates grown on carrot agar were star-shaped with sparse aerial mycelium. Sporangia were predominantly limoniform (Fig. 1), non-caducous, papillated and arranged in irregular sympodial sporangiophores measuring $40 \mu \mathrm{m} \times 32 \mu \mathrm{m}$, with a length/width ratio of 1.3:1. Chlamydospores measuring $25.0 \mu \mathrm{m} \pm 0.3$ in diameter were regularly formed. All seven isolates were heterothallic, forming oospores when mated with an A2 isolate of $P$. palmivora. All cultures grew at $35^{\circ} \mathrm{C}$ The isolates were deposited in the Brazilian Collection of Phytophthora under accession numbers CBP 1179-1185. Based on morphological and physiological criteria (Stamps et al., 1990; Waterhouse, 1963; Gallegly \& Hong, 2008) all isolates were identified as $P$. nicotianae. The ITS sequences obtained for isolates CBP 1179, CBP 1183, and CBP 1185 (JF326834, JF326835 and JF326836 respectively) were identical. These sequences most closely matched that of isolate STEU6273 of $P$. nicotianae (GU902246) with 99\% identity.

Pathogenicity tests were done by inoculating detached leaves of $D$. sanderiana with $5 \mathrm{~mm}$ mycelial agar discs of five-day-old cultures of each of the seven isolates. Inoculated leaves and controls treated with sterile agar discs were kept in moistened plastic bags at $25^{\circ} \mathrm{C}$. Lesions developed five days later only on inoculated leaves. All seven isolates caused symptoms similar to the ones observed in the field and $P$. nicotianae was re-isolated from the infected leaves. Phytophthora spp. are pathogens of various ornamental plants in Brazil (Paim et al., 2006; Silva et al., 2001) and $P$. nicotianae is one of the most prevalent species in Brazil, causing disease in many important crops such as pineapple, citrus, onion, and tobacco, among others. To our knowledge, this is the first time this pathogen was found on $D$. sanderiana in Brazil and worldwide. It is possible that the pathogen has recently adapted to infect $D$. sanderiana from pineapple, citrus and tobacco plants growing nearby the nurseries. Further molecular studies will show whether this is the case.P. nicotianae causes severe damage to $D$. sanderiana in Bahia during the rainy season. The pathogen destroys the leaves, which are the most valuable commercial part of the plant. Additional studies are necessary to determine its potential risk to commercial plantations.

\section{Acknowledgements}

The authors would like to thank CEPLAC and the CNPq for financial support.

\section{References}

Gallegly ME, Hong CX, 2008. Phytophthora: Identifying Species by Morphology and DNA Fingerprints. St. Paul, MN, USA: APS Press.

Kannwischer ME, Mitchell DJ, 1978. The influence of a fungicide on the epidemiology of black shank of tobacco. Phytopathology 68, 1760-1765. [doi:10.1094/Phyto-68-1760]

Paim MCA, Luz EDMN, De Souza, JT, Cerqueira, AO, Lopes, JRM,

2006. Pathogenicity of Phytophthora species to Anthurium andraeanum in Brazil. Australasian Plant Pathology 35, 275-277.

[doi:10.1071/AP06005]

Silva AMS, de Araújo JS, do Carmo MGF, 2001. Doenças de plantas ornamentais causadas por Phytophthora. In: Luz EDMN, Dos Santos AF, Matsuoka K, Bezerra JL, eds. Doenças causadas por Phytophthora no Brasil. Campinas: Livraria e Editora Rural, 590-604.

Stamps DJ, Waterhouse GM, Newhook FJ, Hall GS, 1990. Revised tabular key to the genus Phytophthora. Mycological Papers 162. Wallingford, UK: CABI.

Waterhouse GM, 1963. Key to species of Phytophthora de Bary. Mycological Papers 92. Wallingford, UK: CABI.

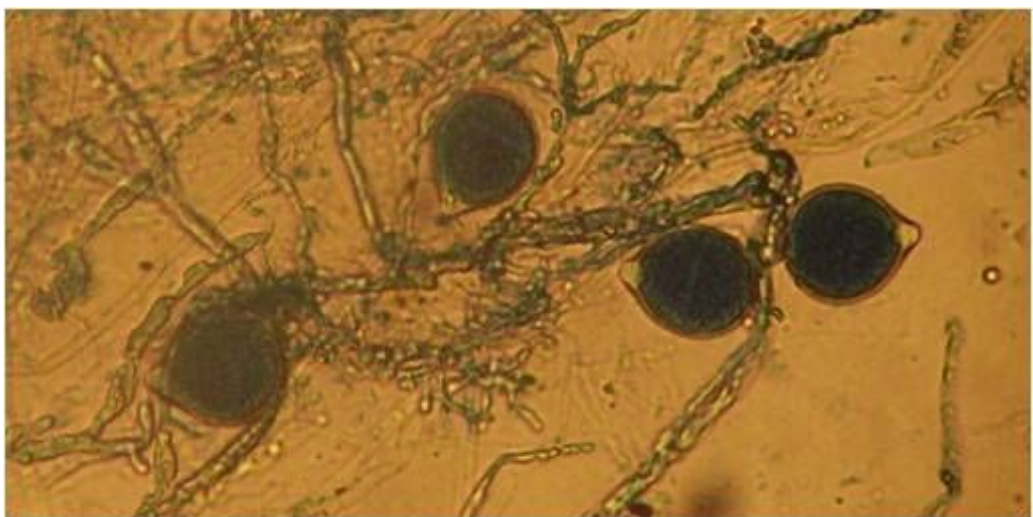

Figure 1

To cite this report: Dos Santos MVO, Luz EDMN, de Souza JT, 2011. First record of Phytophthora nicotianae causing leaf blight on Dracaena sanderiana. New Disease Reports 24, 28. [doi:10.5197/j.2044-0588.2011.024.028]

(c) 2011 The Authors

This report was published on-line at www.ndrs.org.uk where high quality versions of the figures can be found. 